\title{
Rousseau e a educação popular
}

\author{
Ana Cristina Armond ${ }^{1}$ \\ José Benedito de Almeida Júnior ${ }^{2}$ \\ Regiani Cristina Jacinto Ferreira ${ }^{3}$
}

\begin{abstract}
Resumo: O objetivo deste artigo é apresentar os princípios de uma educação popular a partir das obras de Jean-Jacques Rousseau, especialmente $O$ Emílio ou da Educação e Considerações sobre o governo da Polônia. Apesar de Rousseau não ter utilizado o termo educação popular, este princípio aparece na obra Considerações quando ele observa que todos deveriam ter acesso à escola, pobres ou ricos. Ambas as obras estão unidas conceitualmente mesmo tendo diferentes propósitos. Quanto à questão da relação entre natureza e cultura para Rousseau observa-se que a educação da natureza, fundamentada no Emílio, não significa deixar a natureza educar a criança por si só, mas se propõe uma educação conforme e não contra a natureza. Portanto, Rousseau não é um crítico da cultura, mas de certo tipo de cultura que violenta o ser humano em favor de uma aparência de ordem e civilização.
\end{abstract}

Palavras-chave: Educação. Popular. Natureza. Cultura. Rousseau.

\section{Rousseau and popular education}

Abstract: The aim of this article is to present the principles of popular education based on the works of Jean-Jacques Rousseau, especially the Emile or the Education and Considerations of the Government of Poland. Althought Rousseau did not use the expression popular education this principle appears in the work Considerations when he observes that everyone should have access to school, poor or rich. Both works are conceptually united even though they have different purposes. About of the question of the relationship between nature and culture, for Rousseau, it is observe that the education of nature, based on Emilio, does not mean letting nature educate the child by itself, but it proposes an education that is in conformity and not against nature. Therefore, Rousseau is not a critic of culture, but of a certain type of culture, that violates human beings in favour of appearance of order and civilization.

Keywords: Education. Popular. Nature. Culture. Rousseau.

\footnotetext{
${ }^{1}$ Mestra em Filosofia. Aluna especial do programa de doutorado do Programa de Pós-Graduação em Filosofia da Universidade Federal de Uberlândia. E-mail: acristinaarmond@gmail.com. Orcid: https://orcid.org/0000-0001-9421-834X.

${ }^{2}$ Professor Doutor do Instituto e do Programa de Pós-Graduação em Filosofia da Universidade Federal de Uberlândia. Orcid: https://orcid.org/0000-0001-5801-7284.

${ }^{3}$ Mestra em Filosofia. Aluna especial do programa de doutorado do Programa de Pós-Graduação em Filosofia da Universidade Federal de Uberlândia. E-mail: regianicj@hotmail.com. Orcid: https://orcid.org/0000-0001-5121-7961.
} 


\section{Rousseau y la educación popular}

Resumen: El objetivo de este artículo es presentar los principios de la educación popular basados en la obra de Jean-Jacques Rousseau, especialmente El Emilio o de la Educación y Consideraciones sobre el gobierno de Polonia. Aunque Rousseau no utilizó el término educación popular, este principio aparece en la obra Consideraciones, cuando observa que todos deben tener acceso a la escuela, pobres o ricos. Ambas obras están unidas conceptualmente aun que tienen propósitos diferentes. En cuanto a la cuestión de la relación entre naturaleza y cultura, para Rousseau se observa que la educación de la naturaleza, basada en Emile, no significa dejar que la naturaleza eduque al niño por sí misma, sino que propone una educación conforme y no contra la naturaleza. Por tanto, Rousseau no es un crítico de la cultura, sino de un cierto tipo de cultura que viola al ser humano en favor de una apariencia de orden y civilización.

Palabras clave: Educación Popular Naturaleza Cultura Rousseau

\section{Introdução}

Jean-Jacques Rousseau, se não foi o primeiro, foi, com certeza, um dos primeiros filósofos da modernidade europeia que proporá a necessidade de que todos tenham direito à escola, conforme vemos em sua obra Considerações sobre o governo da Polônia, publicada em 1771: "Todos, sendo iguais pela constituição do Estado, devem ser educados juntos e da mesma maneira e se não se pode estabelecer uma educação pública totalmente gratuita, é preciso ao menos oferece-la a um preço que os pobres possam pagar.” (1982, p. 37). O conteúdo a ser apresentado nesta escola, segundo suas palavras, não se configura exatamente como o que hoje entendemos por educação popular, porém, trata-se de uma postura muito progressista para seu tempo: que os jovens poloneses tivessem como conteúdo escolar assuntos relativos a sua vida prática, imediata e não somente os estudos que fizessem parecer estar aprendendo coisas importantes, mas sem qualquer relação com seu cotidiano e sua história.

$\mathrm{O}$ acesso de todas as crianças e adolescentes à rede de educação, que cada um e cada uma tenha sua vaga assegurada e uma estrutura adequada para a vivência escolar, chamamos de direito universal à educação. $\mathrm{O}$ conteúdo das disciplinas e o direcionamento dos trabalhos escolares é que darão o sentido de uma educação popular ou de uma educação livresca. A escola, portanto, é o meio no qual o processo de educação formal ou escolar ocorre; o conteúdo desta educação é definido pelos princípios que nortearão a práxis escolar.

Neste sentido, sem dúvida alguma, Rousseau é um fortíssimo crítico da escola de seu tempo sobre três aspectos: são caras e excluem os mais pobres; os conteúdos ali 
ensinados estão absolutamente desligados da realidade dos estudantes; as normas morais de relacionamento na escola são repletas de vícios que transformam os jovens em egoístas, portanto pessoas sem qualquer empatia e sociabilidade. Em duas obras diferentes esta crítica à escola de seu tempo aparece de modo bastante enfático. No Emílio lemos: "Não encaro como uma instituição pública esses estabelecimentos ridículos a que se chamam colégios.” (1992, p. 14). Nas Considerações afirma: "Um francês, um inglês, um espanhol, um italiano, um russo, são mais ou menos o mesmo homem; ele sai do colégio já totalmente moldado pela licenciosidade, isto é, pela servidão.” (1982, p. 36)

\section{Natureza e cultura}

Começamos essa parte da reflexão citando uma carta de Rousseau, na qual ele foi novamente obrigado a explicitar os princípios de sua obra, muito lidos, pouco compreendidos e criticados a partir de más interpretações. No trecho, citado por Jean Chateâu (1964) podemos constatar Rousseau afirmando em sua carta à Philibert Cramer, datada de 13 de outubro de 1764 que:

Você acerta quando diz qual foi meu objetivo e que o livro que tem este título seja um verdadeiro tratado de educação? É uma obra assaz filosófica sobre este princípio avançado pelo autor em outros escritos, que o homem é naturalmente bom. (1964, p. 94)

As reflexões sobre as relações entre natureza e cultura eram bastante intensas ao longo do século XVIII e assim permaneceram até nossos tempos. A questão é, em relação ao comportamento humano: até onde podemos dizer que nossos comportamentos são naturais, logo encontrados em todas as sociedades independentemente da época histórica e até onde nossos comportamentos são consequência da cultura? No século das Luzes o termo cultura era geralmente reservado para a prática agrícola, sendo assim, as expressões usos e costumes indicavam a cultura, como usamos hoje. Ora, Rousseau enfrenta esta questão em diversas obras, sendo três as mais evidentes: O discurso sobre as ciências e as artes (1751), o Discurso sobre a desigualdade entre os homens (1756) e o Emilio, ou da educação (1762). Infelizmente, por uma questão de espaço, não poderemos analisar, neste trabalho, as duas primeiras, faremos, então, uma breve apresentação das suas relações com o Emilio. 
A primeira destas obras traz uma visão bastante crítica do impacto que o desenvolvimento das ciências e das artes oferece aos usos e costumes e Rousseau, demonstra com diversos exemplos históricos que o desenvolvimento cultural das sociedades resultou em sua decadência moral e política, sendo dominadas por outras sociedades menos avançadas neste campo. Posteriormente, em suas Confissões, se redime dos argumentos desta obra e a renega como a mais fraca de seu repertório. Seguindo, pois, sua decisão, podemos dizer que os argumentos de Rousseau contra os efeitos do desenvolvimento das artes e das ciências são realmente inadmissíveis, mas algo desta obra permanecerá em reflexões futuras: o artificialismo de uma cultura livresca que tenta se impor à natureza.

A segunda destas obras é considerada, pelo próprio autor, uma de suas melhores e não foi renegada. Nesta, demonstra que a desigualdade entre os homens não é resultado da natureza e sim das instituições sociais. Para muitos de seu tempo - e ainda dos nossos - a desigualdade entre as pessoas é resultado apenas dos diferentes potenciais que cada um traz consigo desde o nascimento, assim, a riqueza de um e a pobreza de outro seriam explicadas facilmente pelas diferenças entre as pessoas. Rousseau admite que todos os seres humanos são diferentes entre si, no entanto, estas diferenças naturais não são suficientes para explicar as enormes diferenças de condições na sociedade. A miséria, a pobreza, a exclusão de serviços fundamentais à vida como saúde e educação são provocadas por políticas públicas que definem se a maioria das pessoas devem ser contempladas com os serviços essenciais. Logo a cultura é a causa da desigualdade entre as pessoas e não a natureza.

Rousseau tem uma absoluta confiança na natureza e, portanto, que ela jamais nos conduziria a movimentos contraditórios ou à injustiça e a à desigualdade. Esta confiança deriva de sua fé cristã: para ele, a natureza sendo obra de Deus não poderia estar errada, conforme vemos logo nas primeiras palavras do Emílio ou da educação: "Tudo é certo em saindo das mãos do Autor das coisas, tudo degenera nas mãos do homem." (ROUSSEAU, 1992, p. 9). Da mesma forma, constatamos o mesmo em sua polêmica com o arcebispo de Paris Christophe Beaumont a respeito do pecado original:

Para Rousseau não há maldade original no coração dos homens: “Consideramos que nenhuma criança morta antes da idade da razão será privada da felicidade eterna; os católicos acreditam a mesma coisa de todas as crianças que receberam o batismo." (1992, p. 296) O Arcebispo de Paris, que conseguiu censurar o Emílio afirma na carta 
em que determina esta censura, tomando as palavras de Rousseau como uma afronta ao princípio do pecado original:

Nessa linguagem não se reconhece absolutamente a doutrina das santas Escrituras e a da Igreja no que tange à revolução que ocorreu em nossa natureza (...) Sim, meus caríssimos irmãos, há dentro de nós uma impressionante mistura de grandeza e mesquinharia, de paixão pela verdade e gosto pelo erro, de inclinação para a virtude e tendência para o vício. Espantoso contraste que, ao desconcertar a filosofia pagã, a faz divagar em vãs especulações; um contraste cuja origem a revelação nos desvenda na queda deplorável de nosso primeiro pai! (2005, p. 221)

Rousseau, por sua vez, considera que a ideia de pecado original the parece contrária à sua concepção de Deus e contraditória ao catecismo católico:

Não é porventura o sangue de Cristo suficientemente forte para apagar completamente a mancha, ou seria esta antes um efeito da corrupção natural de nossa carne, como se Deus - mesmo independentemente do pecado original - tivesse nos criados corrompidos, expressamente para ter o prazer de nos punir? O senhor atribui ao pecado original os vícios de pessoas que admite terem sido liberadas do pecado original; e a seguir me censura por ter dado uma outra origem a esses vícios. É justo transformar num crime o fato de não ter raciocinado tão mal quanto o senhor? $(2005$, p. 50)

Rousseau, não negará a importância da cultura para as sociedades, mesmo porque o gênero humano não vive sob o simples impulso da natureza - como os outros animais - há milhares de anos. A questão, portanto, não é conflito entre a natureza e a cultura, mas quais tipos de usos e costumes se quer cultivar. Há uma cultura que quer sufocar e desvirtuar a natureza e uma cultura que interage com ela de forma muito mais saudável do que o exemplo de nossas sociedades. Aqui, devemos colocar em destaque um aspecto do campo político antes de seguirmos adiante.

Thomas Hobbes e Rousseau assumem posturas diferentes frente ao problema da natureza humana. Como sabemos, Hobbes em seu Leviatã dirá que a natureza humana nos conduz a um comportamento insociável e que, portanto, a função do Estado é reprimir esta natureza para que tenhamos condições de viver em grupo. Hobbes argumenta da seguinte forma, sobre sua tese:

Que seja, portanto, ele a considerar-se a si mesmo, que quando empreende uma viagem se arma e procura ir bem acompanhado; que quando vai dormir fecha suas portas; que mesmo quando está em casa 
tranca seus cofres; e isto mesmo sabendo que existem leis e funcionários públicos armados, prontos a vingar qualquer injúria que lhe possa ser feita. Que opinião tem ele de seus compatriotas, ao viajar armado; de seus concidadãos, ao fechar suas portas; e de seus filhos e servidores, quando tranca seus cofres? Não significa acusar tanto a humanidade com seus atos como eu o faço com minhas palavras? (HOBBES 1988, p. 76)

Os impulsos para o egoísmo, para a ganância, dominação do outro etc. não são, para Rousseau, fruto da nossa natureza, mas dos valores que nossas sociedades inculcam em cada um. Lembro aqui de quando da greve da polícia no Estado do Espírito Santo houve uma série de saques às lojas o que deu ocasião para alguns considerarem, do ponto de vista hobbesiano, que sem a polícia e o Estado os seres humanos se auto destruiriam. Outros, observando de forma mais criteriosa notaram que apenas uma mínima parte da população envolveu-se nos saques às lojas, mesmo com a ausência da polícia, logo, se fosse uma questão de natureza, todos teriam se envolvido. O que esta situação revela é uma retórica de ocultamento hipócrita: muitos pretendem ocultar suas escolhas alegando que são impulsos da natureza.

Rousseau, portanto, não é um crítico da cultura, mas de certo aspecto da cultura que pretende, como dissemos calar a natureza e disfarçar suas escolhas morais como impulsos da própria natureza. Assim, alguns estudiosos do pensamento de Rousseau, acabaram por confundir suas críticas à determinado tipo de cultura (neste nosso trabalho, a educação livresca) com uma crítica generalizada da cultura. As contradições que vivemos não são decorrentes da natureza, mas das diferentes formas de nos relacionarmos com ela. Vejamos, muito brevemente, a concepção de natureza de Rousseau na perspectiva de dois estudiosos.

Para Derrida, Rousseau apesar de preso à concepção da metafísica clássica, apresentaria uma perspectiva diferente da "oposição ideológica própria da Metafísica" (DERRIDA apud FORTES, 1976, p. 56) que estabeleceria a noção de suplementariedade. A origem e a natureza passam a ser ocultas pelo suplemento, por uma máscara.

Fortes, por sua vez, faz uma severa crítica à leitura de Derrida, pois ela não contribui para a compreensão da obra, especialmente em virtude de sua estratégia metodológica, pois, Rousseau "não parecia preocupado em constituir uma nova língua, mas em usar da velha para fazê-la veicular significações novas” (1976, p. 57). Este 
projeto de demarcar limites entre obras filosóficas fundamentada pela metafísica e obras que escapam a esse limite, não parecem, em nosso ponto de vista, muito promissor.

Nossa questão não é a interpretação de Derrida e o problema da metafísica, mas à solução que Fortes apresenta para responder o autor da Gramatologia. Para Fortes:

\begin{abstract}
A consulta aos textos torna possível, segundo parece, a definição de uma estrutura de suplementariedade neles operante e que pode ser formalmente descrita nos seguintes termos: a natureza, termo tão freqüente nos textos e associado claramente a termos como mãe e mulher, possui uma estrutura contraditória no sentido de que reclama e recusa, por assim dizer, simultaneamente uma suplementação como se ela, ao mesmo tempo, se bastasse ou não a si mesma. (1976, p. 57, grifos nossos)
\end{abstract}

Parece-nos que esta tese não é adequada ao pensamento rousseauísta, ou seja, que a natureza possua uma estrutura contraditória. A contradição não se encontra na natureza, mas na sociedade, ou melhor, na relação entre a natureza e a sociedade. No Emílio lemos: “Arrastados pela natureza e pelos homens por caminhos contrários, obrigados a nos desdobrarmos entre tão diversos impulsos [...]” (1992, p. 14); se há contradição esta não se encontra a natureza. A tese de Fortes nos conduz ainda há uma outra dificuldade: como podemos seguir os passos da natureza se ela possui uma estrutura contraditória como nós poderíamos seguir seus passos e os caminhos por ela indicados? A ideia de que é preciso a ação humana para que a natureza seja completa nos remete aos contemporâneos que Rousseau tanto criticava, tal como neste trecho do Emilio:

Dizem que muitas parteiras pretendem, com massagens na cabeça das crianças recém-nascidas, dar-lhe uma forma mais conveniente, e aceita-se isso! Nossas cabeças estariam erradas, se em obediência ao Autor do nosso ser; cumpre-nos modelá-las de fora pelas parteiras, e, por dentro, pelos filósofos. Os caribes são metade mais felizes do que nós. (1992, p. 17)

Ora, a natureza não é contraditória em si, porém a vida em sociedade não poderia subsistir apenas seguindo seus impulsos, então, precisamos observar criteriosamente em que medida o processo educacional deixa os movimentos da natureza livres e em que medida estes devem ser conduzidos para outro fim. No início do Emilio Rousseau nos apresenta uma metáfora que exprime sua concepção. 
A natureza, dizem-nos, é apenas o hábito. Que significa isso? Não há hábitos que só se adquirem pela força e não sufocam nunca a natureza? É o caso, por exemplo, do hábito das plantas cuja direção vertical se perturba. Em se lhe devolvendo a liberdade, a planta conserva a inclinação que a obrigaram a tomar; mas a seiva não muda, com isso, sua direção primitiva; e se a planta continuar a vegetar, seu prolongamento voltará a ser natural. (1992, p. 11-12)

É importante lembrar que, apesar de ter tido apenas dois anos de educação formal, Rousseau dedicou-se ao estudo de várias áreas, inclusive a herbologia, por isso, ele fala de plantas com conhecimento. Ao final da sua vida escreverá algumas obras sobre plantas. Enfim, a ideia é de que possuímos uma natureza, mas quando recebemos a educação a natureza se modifica adaptando-se à inclinação que lhe foi dada. Como Rousseau parte do princípio de que, por natureza, todos somos iguais e tendemos ao bem, então, se alguém se torna malvado ou egoísta, isso se deve, somente à educação e não à natureza ou à qualquer inclinação natural para o mal. No Discurso sobre a desigualdade dirá que só reconhece dois sentimentos naturais no ser humano: o amor de si e a piedade natural. $\mathrm{O}$ amor de si é o que hoje chamamos de auto cuidado, diferente do amor próprio, que seria um sentimento de egoísmo desenvolvido já em sociedade. A piedade natural é o sentimento de comiseração que temos ao ver o sofrimento de qualquer outro ser sensível. Pode-se dizer que pela natureza o ser humano é amoral, não possui as virtudes, nem os vícios naturalmente.

Da mesma forma que não é um crítico da cultura simplesmente, mas de certo tipo de cultura, Rousseau considera que é necessário refletir detidamente sobre as paixões humanas. Para ele, mesmo sendo as paixões pertencentes à natureza humana isso não significa que todas as paixões que sentimos são naturais. Há paixões que são produzidas - conforme vimos anteriormente - no convívio da sociedade. Desta forma, alguns filósofos consideraram que as paixões são a perdição da racionalidade e da existência humana e formaram o quimérico projeto de querer controlar a existência por meio da racionalidade ao modo dos geômetras. Rousseau critica duramente esta postura.

Nossas paixões são os principais instrumentos de nossa conservação: é portanto empresa tão vã quão ridícula querer destruí-las; é controlar a natureza, é reformar a obra de Deus. Se Deus dissesse ao homem que aniquilasse as paixões que lhe dá, Deus quereria e não quereria; estaria em contradição consigo mesmo. Nunca ele deu tão insensata ordem, nada de semelhante está escrito no coração humano; e o que Deus quer que um homem faça não o faz dizer por outro homem; di-lo ele próprio, escreve-o no fundo do coração do homem. Eu acharia, quem quisesse impedir as paixões de nascerem, quase tão louco quanto 
quem as quisesse aniquilar. $\mathrm{E}$ os que pensassem tal fosse minha intenção até aqui, ter-me-iam certamente muito mal compreendido. (1992, p. $234-235)$

Em resumo até aqui, podemos ver que para Rousseau, os impulsos da natureza não podem nos levar para os vícios da sociedade, nem também às virtudes propriamente, então estas devem ser aprendidas pela cultura. Logo ele não é um crítico da cultura, mas a certo tipo de cultura, a qual podemos definir como artificial que torna os homens malvados e egoístas. Neste sentido, vale a pena, antes de adentrar nas questões relativas à educação popular, fazer duas breves comparações de duas circunstâncias em que a cultura nos leva a uma sociabilidade ética ou a uma sociabilidade artificial. Trata-se dos casos dos jardins e das festas.

No excerto abaixo, da Carta a M. D’Alembert, Rousseau destaca a necessidade da criação de festas públicas, ao ar livre, nas quais os cidadãos possam confraternizar-se livremente. Opõe a este modelo o teatro como divertimento público, pois, como ele diz, trata-se de um antro fechado no qual os espectadores são obrigados a ficarem imóveis. Lembra-nos, sem dúvida, os modelos de escola sob os auspícios da influência industrial, na qual as crianças são forçadas a ficarem imóveis nas suas cadeiras por horas e, o pior de tudo, numa situação mental de passividade, somente recebendo conteúdo, tal como descreverá Paulo Freire, no século XX como educação bancária:

Como! Não deve haver nenhum espetáculo numa República? Pelo contrário! Deve haver muitos deles. Nas Repúblicas eles nasceram, nelas os vemos brilhar com um real ar de festa. A que povos convém mais reunir muitas vezes seus cidadãos e travar entre eles os doces laços do prazer e da alegria, do que aos que têm tantas razões para se amarem e para permanecerem unidos para sempre? Já temos os prazeres dessas festas públicas; tenhamo-nas em ainda maior número, e ficarei ainda mais encantado. Mas não adotemos esses espetáculos exclusivos que encerram tristemente um pequeno número de pessoas num antro escuro; que as mantêm temerosas e imóveis no silêncio da inação; que só oferecem aos olhos biombos, pontas de ferro, soldados, aflitivas imagens da servidão e da desigualdade. Não, povos felizes, não são essas as vossas festas! É ao ar livre, é sob o céu que devais reunir-vos e entregar-vos ao doce sentimento de vossa felicidade! (ROUSSEAU, 1993, p. 128)

No que tange aos jardins, a ideia é a mesma: não se trata de um conflito entre natureza e cultura, mas um conflito em como culturas diferentes se relacionam com a mesma matriz, a natureza. Não é, pois, a natureza que possui uma estrutura contraditória, mas a contradição encontra-se entre diferentes projetos de cultura. Neste 
sentido, uma educação livresca destinada à elite e à exclusão da maioria se opõe a uma educação popular, no sentido mais amplo desta palavra. Vejamos, pois a comparação de Rousseau em sua obra A Nova Heloísa sobre os diferentes tipos de jardins. Quando o autor se remete ao termo jardim, devemos ter em mente que se tratam de verdadeiros bosques ou parques privados por onde se faz caminhadas para exercício ou "descanso do espirito" (1994, p. 418). Há jardins em que a arte se sobrepõe à natureza, impedindo o desfrute mais adequado destes jardins; Rousseau narra a experiência de um jardim de flores em Londres em que, apesar de toda a beleza das plantas, não fornece uma experiência de passeio, mas de uma exposição de arte. Neste sentido ele diz:

O mesmo se passa em relação à educação livresca e a educação natural que, neste artigo, consideramos que trazem os princípios de uma verdadeira educação popular, pois não é artificial, onde, numa linguagem rousseauísta, o ser é mais importante do que o parecer. Assim, vemos que não há uma rejeição da arte ou da cultura, mas de fazer com que esteja em harmonia com ela. Assim descreve, Rousseau, o que seria um jardim que estivesse em pleno acordo com a natureza e cumprindo seu propósito de proporcionar prazer e descanso, ao invés de inflar os orgulhos:

Que fará, portanto, o homem de gosto que vive por viver, que sabe gozar de si mesmo, que procura os prazeres verdadeiros e simples e que deseja criar uma avenida à porta de sua casa? Ele a fará tão cômoda e tão agradável que nela possa comprazer-se em todas as horas do dia e contudo tão simples e tão natural que pareça nada ter feito. Reunirá a água, a verdura, a sombra e o frescor, pois a natureza também reúne todas estas coisas. A nada dará simetria, ela é inimiga da natureza e da variedade e todas as alamedas de um jardim comum se assemelham tanto que temos a impressão de estar sempre na mesma. (1994, p. 419, o destaque é nosso).

Observamos que a ideia permanece a mesma nas Considerações conforme citamos mais acima quando Rousseau afirma que um inglês, um francês, um russo se parecem, mais ou menos o mesmo homem, assim como os jardins acabam também se parecendo todos. A causa destas semelhanças é a artificialidade com que se fazem os jardins e se educam as pessoas de tal forma a não deixar transparecer a natureza, mas sobressaltar o trabalho da arte. Não se valoriza o que há de mais original e autêntico em cada região, mas se pretende lançar uma máscara de civilização, sobre a natureza e chama isso de o ideal do iluminismo. Para Rousseau, sejam em relação à educação, aos jardins ou às festas públicas, o ideal é deixar a natureza ditar o rumo, deixar com que cada cultura tem de particular manifestar-se livremente, por isso, apesar de 
frequentemente listado entre os iluministas, ele é uma voz contrária a este projeto que tende a tornar tudo igual a fim de agradar o que se acha um gosto refinado e que é justamente o oposto disto: uma civilização grosseira. Para Rousseau, é preciso observar a natureza e seguir o caminho que ela indica, mas isso parece tão difícil para as pessoas da sociedade que vivem de aparências.

\section{Seguir a natureza}

Em uma das suas máximas mais conhecidas, Rousseau dirá que seguir a natureza não é deixar de educar ou aplicar a arte da educação, mas é aprender com ela, tal como faz o agricultor, para que o potencial da natureza se manifeste é preciso uma arte que esteja em harmonia com ela:

Observai a natureza e segui o caminho que ela vos indica. [...] Essa a regra da natureza. Por que a contrariais? Não vedes que, pensando corrigi-la, destruís sua obra, impedis o efeito de seus cuidados? Fazer por fora o que ela faz por dentro é, a vosso ver, aumentar o perigo; e, ao contrário, é provocar uma diversão, é atenuá-lo. (1992, p. 24-25)

A questão é, portanto, educar observando o desenvolvimento natural das crianças. Estas ideias de Rousseau influenciaram a pedagogia posterior a ele, sendo que podemos destacar Pestalozzi. Porém, o mais importante é sua influência no desenvolvimento da psicologia da educação posterior, especialmente Piaget e Vygotsky que se dedicarão a pesquisar os processos de desenvolvimento cognitivo das crianças:

\footnotetext{
Surpreenderiam-nos os conhecimentos do homem mais bronco, se seguíssemos seu progresso desde o momento em que nasceu até àquele a que chegou. Se se dividisse toda a ciência humana em duas partes, uma comum a todos os homens, outra peculiar aos sábios, esta seria muito pequena em comparação com a outra. (1992, p. 42)
}

Havia dois modelos básicos de educação no século XVIII: um deles era o dos preceptores ou educação doméstica, isto é, professores pagos para acompanhar uma ou mais crianças de uma mesma família durante alguns anos e, dividindo-se entre cuidados e ensino, acompanhar o desenvolvimento das crianças. O outro modelo era dos colégios ligados às religiões ou educação pública. Para Rousseau, tanto o modelo de educação doméstica, quanto da pública não são problemas em si, mas a forma como são conduzidos, ou seja, a educação partia da percepção de que sua tarefa era abafar ou 
eliminar os impulsos naturais, até mesmo por influência da ideia de pecado original, isto é, de uma natureza pervertida humana. Aqui vemos esta crítica sob dois pontos de vista.

O primeiro é a própria atitude de muitas pessoas, tanto preceptores, quanto professores que se tornam mais mercenários do que pessoas dedicadas ao saber. $\mathrm{O}$ segundo ponto de vista versa sobre o que se concebia como ensino: as crianças eram obrigadas a memorizar longos trechos de obras clássicas e repeti-las de modo fluente diante da plateia, em geral, composta por familiares e amigos. Isto era o que se chamava ensino: a memorização de conteúdos completamente desconectados da realidade, uma educação livresca. A frase de Rousseau em relação aos colégios, aplica-se também em relação à educação doméstica praticada em seu tempo "Risíveis estabelecimentos a que se chamam colégios" (1992, p. 14).

Do mesmo modo que os jardins e as festas há, para Rousseau, uma educação que segue os caminhos da natureza e sobre a qual a arte deve ser aplicada de tal modo a formar uma pessoa livre e autônoma a qual podemos chamar de educação popular. Ao longo do Emílio encontramos alguns exemplos destes princípios que indicam um processo educativo baseado em saberes populares e não em uma cultura livresca, cujo resultado é a exclusão dos mais pobres de toda possibilidade de ensino. A seguir analisaremos três destes casos de educação popular que se apresentam ao longo do Emilio o caso do jardineiro, o do mágico e, por fim, o aprendizado de um ofício.

O jardineiro Robert é um episódio muito interessante no qual vemos Emílio às voltas com descobertas e problemas: a descoberta é a da maravilha do crescimento de uma planta que ele próprio cultivou e o problema é relativo à noção de propriedade. Emílio observou o crescimento de algumas plantas, pela sutil condução do mestre, e manifestou o desejo de plantar também. Assim, aproveitando-se deste interesse e desejo o mestre prepara o terreno para uma lição. "Em virtude dos princípios aqui estabelecidos, não me oponho a seu desejo. Ao contrário, favoreço-o, compartilho seu gosto, trabalho com ele e não pelo prazer dele, e sim pelo meu; ele o acredita, pelo menos. Torno-me seu ajudante de jardineiro.” (1992, p. 86)

Então, o preceptor e a criança se colocam à plantar algumas favas num terreno e enquanto cuidam diariamente das plantas o preceptor vai lhe ensinando o valor e a relação entre a propriedade e o fruto do trabalho 
Se diariamente regamos a fava, vemo-la despertar com transportes de alegria. Aumento essa alegria dizendo: isto te pertence e explicandolhe, então o tempo pertencer, faço-lhe sentir que pôs naquela terra seu tempo, seu trabalho, sua pena, sua pessoa enfim; que há nessa terra alguma coisa dela própria e que pode reivindicar contra quem quer que seja, como poderia retirar o braço da mão de outro homem que o quisesse segurar contra sua vontade. (1992, p. 86)

A ideia, portanto, é a de que o trabalho gera propriedade, pois há parte do próprio ser em seus resultados. Além disso, a criança juntamente com o preceptor trabalhou diretamente na plantação - evidentemente, todo o trabalho pesado ficou por conta do adulto. O que nos lembra as positivas experiências das hortas nas escolas que despertam nas crianças o encantamento de verem algo resultar de seus esforços e se sentem capazes de criar. Além disso, enquanto cultivam a horta aprendem importantes lições de geografia, história, biologia e outras áreas do saber.

Ocorre, porém, um problema. A horta de favas havia sido plantada num terreno que pertencia a um homem chamado Robert que havia plantado, ali, sementes de melões. Imaginando que as favas haviam nascido como uma praga, Robert as arranca dali e quando aluno e mestre chegam numa bela manhã deparam-se com as favas todas mortas. Rousseau descreve com maestria a angústia do menino diante deste triste espetáculo. O mais importante, porém, ainda estava por vir. É preciso conversar com o jardineiro, saber o que houve e concertar a situação.

Aluno e mestre se desculpam pelos estragos que fizeram na plantação de Roberto e pedem que ele deixe um pequeno pedaço de terra para que possam cultivar suas favas, com a condição de que entreguem uma parte da produção para ele. Este acordo de "meeiro" tem por objetivo permitir ao menino a continuidade da experiência de cultivar plantas e, ao mesmo tempo, não dar prejuízo ao homem que tira seu sustento do trabalho no campo. Assim, as lições sobre história, geografia, biologia, botânica etc. ocorrem ao mesmo tempo que o exercício de sociabilidade e de respeito mútuo entre as pessoas. Além das hortas nas escolas, Rousseau, com certeza admirar-se-ia muito das lições que podemos tirar das plantações coletivas dos assentamentos do MST e outros movimentos dos sem-terra.

O outro caso que acreditamos inspirar a ideia de uma educação popular encontra-se mais adiante na obra, trata-se do episódio do mágico. O mestre e o discípulo estava estudando alguns fenômenos físicos do magnetismo, a partir de imãs, âmbar e outros elementos. Um dia, indo a uma feira, depararam-se com um mágico que fazia um 
marreco de cera mover-se em direção a ele atraído por um pedaço de pão. Ora, marrecos de cera não vão em busca de comida. Então, a dupla prepara um pedaço de pão e no mesmo dia voltam à feira e o menino consegue fazer o mesmo truque do mágico, causando-lhe constrangimento diante do público. O mágico o abraça, o parabeniza e o convida para vir no dia seguinte mostrar seu truque novamente.

Chegado o momento marcado o menino tenta atrair o marreco com seu pedaço de pão e, desta vez, nada acontece. O público o vaia. O mágico por sua vez, consegue fazer o marreco se mover. Então, dá ao menino o pão que usou e ele não obtém sucesso. Novas vaias. O mágico pega o pão do menino, que não havia funcionado e, quando o oferece, faz o marreco mover-se angariando grande aplauso do povo presente. Enfim, agora humilhados, mestre e menino se retiram.

No dia seguinte, recebem, espantados, a visita do mágico em sua casa. Este se mostra bastante contrariado com a atitude deles em tê-lo exposto na feira, ao mostrarem que seus truques até uma criança faz:

No dia seguinte de manhã batem à nossa porta; abro; é o prestidigitador. Queixa-se modestamente de nossa conduta. Que nos fizera para levar-nos a querer desacreditar seus jogos e tirar-lhe o ganha pão? Que pode haver de tão maravilhoso na arte de atrair um marreco para comprar-se tal honra a expensas da subsistência de um homem honesto? (1992, p. $184-185)$

É interessante notar que a situação é a mesma do jardineiro: no processo de aprendizagem de conhecimentos científicos ocorre também o processo de aprendizagem de relacionamentos e direitos. No afã de mostrar que conheciam a ciência desrespeitaram o trabalho do mágico, que vive de mostrar seus truques em público, tal como o jardineiro de suas plantações, colocando em risco seus ganhos. Porém, a lição não acabou aí. Depois do mágico mostrar que quase lhe causaram prejuízo, ele demonstra aos dois qual truque usou para que o pão preparado por Emílio não funcionasse como na vez anterior: além de usar um imã mais potente, o mágico havia pago uma criança para direcionar o marreco sempre em sua direção e jamais na direção de Emílio. Ainda por fim, quando querem, o preceptor e o aluno pagarem por este aprendizado, o mágico dá-lhes inda outro ensinamento: não aceita o pagamento, pois não sendo professor, cobra por seus truques e não por suas lições. 
É com os trabalhadores, jardineiros e mágicos de rua, que Emílio tem suas principais lições sobre propriedade, direitos, relacionamentos humanos. É com estas pessoas que encontra honestidade e disposição para perdoar e ensinar. Rousseau tem em mente, com estes exemplos, mostrar que é entre a gente do povo que se pode tirar verdadeiras lições de sociabilidade. Ele mesmo passou por isto quando ainda adolescente, deixando sua cidade natal e se tornando um errante, recebeu toda a ajuda possível das pessoas simples do campo que o ajudaram a viver até que encontrou abrigo definitivo na casa de Madame Warens. Muitos intérpretes consideram que Rousseau tem uma visão romântica sobre os pobres e, especificamente, sobre os camponeses, mas ele não escreveu estas histórias senão pela vivência direta com as pessoas mais simples, desde sua infância até o início de sua vida adulta. Assim, afirma, de modo muito confiante:

Impressionamo-nos com a felicidade de certas condições, como por exemplo da vida campestre e pastoral. $O$ encanto de ver essa boa gente feliz não é envenenado pela inveja; interessamo-nos por ela verdadeiramente. Por quê? Porque nos sentimos capazes de descer a essa condição de paz e de inocência, de gozar a mesma felicidade; é uma solução que só dá idéias agradáveis, porquanto basta querer gozá-la para o poder (1992, p. 246).

A terceira lição ocorre quando o preceptor decide, para horror dos pais de Emílio, que ele teria de aprender uma profissão, um ofício, o que jamais seria aceito por nobres ou burgueses ricos que desejavam ver seus filhos exercendo profissões de alta sociedade, médicos, advogados, diplomatas, poetas e outras. A primeira observação a este respeito é a seguinte: "Faço questão fechada de que Emílio aprenda um ofício. Um ofício honesto, pelo menos, direis. Que significa esta palavra? Não é honesto todo ofício útil ao público?” (1992, p. 212). A ideia fundamental é de que, ao exercer um ofício, Emílio terá uma experiência mais concreta do que é a vida dos trabalhadores, além do que, também poderá exercitar-se, ao contrário dos ofícios anteriormente citados, nos quais a inação física é uma das características principais. Neste sentido, Rousseau critica a proposta a obra de Locke sobre a educação, que sugere as seguintes profissões para seu pupilo: bordador, dourador ou envernizador. Qual é o problema? São profissões ligadas ao luxo e não às necessidades básicas. Neste trabalho, infelizmente, não poderemos explorar a crítica de Rousseau ao luxo, deve o leitor, no entanto, considerala fundamental neste aspecto. 
O critério da utilidade, portanto, é fundamental conforme ele havia destacado neste mesmo capítulo acerca dos princípios do ensino. Para Rousseau, uma criança aprende com muito mais interesse quando percebe a utilidade do que está vivenciando, lições puramente abstratas na infância não são adequadas. Emílio, neste momento de aprender uma profissão está na adentrando - em nossa concepção hoje - na adolescência e o critério da utilidade permanece importante. Exclui peremptoriamente as profissões que possam representar riscos à saúde, não somente de Emílio, mas de qualquer um que as exerça como é o caso dos envernizadores e pintores que lidam com produtos tóxicos. No entanto, o critério de perigo - como lidar com instrumentos afiados - não é relevante. Depois de tecer várias considerações sobre as profissões de seu tempo Rousseau, finalmente, indica aquele que lhe parece mais adequada:

Tudo bem pesado, o ofício que apreciaria fosse do gosto de meu aluno é o de marceneiro. É limpo, é útil, pode exercer-se em casa; mantém suficientemente o corpo em atividade, exige do operário engenho e habilidade e a elegância e o gosto não se excluem da forma das obras que a utilidade determina. (1992, p. 222)

A ideia de aproximar Emílio das profissões populares é muitíssimo interessante porque, sendo filho de pessoas de posse, Emilio ficaria distante da realidade de como se produz os objetos que todos utilizam. O conhecimento da origem, do esforço e do conhecimento necessários para produzir objetos comuns de uso cotidiano dará a ele uma dimensão humana que não era prevista na educação elitista de seu tempo que, além de não ensinar estas profissões aos filhos da elite econômica, ainda estimulava o desprezo aos conhecimentos e vivências das pessoas das camadas economicamente desfavorecidas. A profissão escolhida - marcenaria - une os critérios de utilidade, de trabalho físico e um certo risco que mantém o jovem alerta. Por meio de sua experiência, poderá dimensionar o fruto das outras profissões e saber o quanto as pessoas trabalham para produzir aquilo que parecia tão banal aos nobres e burgueses ricos de seu tempo.

Antes de encerrarmos, faz-se necessário comentar uma passagem do início do Emílio que se relaciona com a questão da educação e profissão. Numa primeira leitura, podemos entender que Rousseau está desvalorizando a situação social dos pobres. Suas palavras são as seguintes: "O pobre não precisa de educação; é obrigatória a de sua condição, não poderia ter outra. Ao contrário, a educação que o rico recebe de sua condição é a que menos lhe convém tanto para si mesmo quanto para a sociedade". 
(1992, p. 29) Neste excerto Rousseau não se refere à escola pública como fará na obra Considerações sobre o governo da Polônia, publicada anos mais tarde, mas à educação doméstica ou natural. O que ele está dizendo é que as pessoas pobres - e não as que vivem em condição de miséria - recebem uma educação doméstica adequada à sua condição, isto é, equilibrando necessidade, utilidade e aprendizados. Sua crítica é dirigida à educação doméstica que as pessoas ricas recebiam, completamente prejudiciais para as crianças e sem qualquer utilidade para a sociedade. Ao final deste raciocínio conclui que para demonstrar suas ideias é melhor dedicar-se à educação de um rico: "Escolhamos portanto um rico; teremos certeza, ao menos de ter feito um homem a mais, ao passo que um pobre pode tornar-se homem sozinho.” (1992, p. 29) Quando afirma, portanto, "o pobre não precisa de educação" demonstra confiar nas tradições populares - que elogia largamente em toda obra - e, ao contrário, confiar muito pouco na artificialidade da educação dos ricos.

\section{A educação nacional}

Na obra Considerações sobre o governo da Polônia e sua reforma projetada, vemos Rousseau insistir na importância da educação nacional: "Eis aqui o artigo importante. É a educação que deve dar às almas o caráter nacional e dirigir de tal forma suas opiniões e seus gostos que eles sejam patriotas por inclinação, por paixão, por necessidade." (1982, p. 36). Este discurso é bem oposto hoje do que conhecemos como educação popular ou mesmo uma educação libertadora como a de Paulo Freire. No entanto, devemos analisar o contexto para o qual Rousseau está escrevendo. Podemos dizer que ele possui obras teóricas, como Do Contrato Social em que apresenta noções gerais sobre a filosofia política, que estão acima das circunstâncias específicas de qualquer país em particular. Por outro lado, há obras de circunstância, na qual ele está pensando um situação específica, como suas Cartas escritas da montanha e As considerações.

Esta obra foi escrita a pedido do conde Wielhorski que pretendia levar a cabo, na Polônia, uma modernização da constituição com o objetivo de fortalece-la num cenário geopolítico em que ela estava sempre ameaçada pelas potências ocidentais e pela Rússia, ao oriente, a Polônia era um país politicamente frágil naquelas condições. $\mathrm{O}$ fato de ser composta por diversas etnias nem é o principal fator, mas sua história política que a tornava frágil diante dos interesses estrangeiros. Rousseau é encarregado de propor 
uma constituição para a Polônia, ao modo dos antigos legisladores gregos e romanos. Então, de posse das informações ele faz algumas propostas para o fortalecimento desta nação. O trecho acima citado começa com a expressão "Eis aqui o artigo importante", ou seja, para ele, é a educação que promoveria a mudança de condição geopolítica da Polônia no cenário europeu. Como ele dirá mais adiante: “Aos vinte anos um polonês não deve ser um outro homem; deve ser um polonês." (1982, p. 36)

O conteúdo da educação, no entanto, pode parecer aos nossos olhos hoje, próximo dos discursos nacionalistas que foram usados para justificar regimes totalitários, elegendo heróis que representariam o domínio da classe economicamente privilegiada em oposição às classes populares. Por isso, devemos ler estes trechos na perspectiva de Rousseau e não na nossa. Ora, a Polônia tinha uma fortíssima crise de identidade nacional e, para solucionar isto, era necessário reforçar o espírito nacional, mas em Rousseau, podemos entender como espírito nacional o cidadão e não um mero nacionalismo que serve como máscara para disfarçar o discurso ideológico da elite econômica. Por isso ele sugerirá:

Quero que, aprendendo a ler, leia coisas de seu país, que aos dez anos conheça todas as suas produções, aos doze todas as províncias, todos os caminhos, todas as cidades, que aos quinze anos saiba toda a sua história, aos dezesseis todas as leis, que não tenha havido em toda a Polônia uma bela ação nem um homem ilustre de que não tenha memória e o coração plenos e de que não possa dar conta imediatamente." (1982, pp. 36-37)

Rousseau está se referindo a uma nação com fortíssima crise de identidade, onde os mais pobres não tinham acesso à educação e os mais ricos tomavam por educação o conhecimento de outras culturas e nações que não a própria, sabiam mais a história de outras nações do que a própria. Enfim, no caso da Polônia, valorizar a própria história era fundamental para construir um espírito, mais do que pátrio, cidadão.

Por isso, se os saberes populares não são destacados para a Polônia, como foram no Emílio é por conta do objetivo em cada obra e se nós as juntarmos veremos que é facilmente deduzível que por meio da leitura do Emílio logo veriam a importância de valorizar os saberes populares. Um tópico, por exemplo, que está presente em ambas as obras é a educação negativa, definida por Rousseau como um meio de ao invés de ensinarmos conteúdos, podemos conduzir os alunos a desenvolver determinados conteúdos por si mesmos o que reforça em muito o aprendizado. Não se trata de 
abandonar os alunos para que aprendam por si mesmos, mas conduzir o processo pedagógico, fornecendo suporte teórico e metodológico para que pensem por si mesmos. Em suas palavras:

Não direi nunca o bastante que a boa educação deve ser negativa. Impeçam os vícios de nascer e tereis feito o suficiente pela virtude. $\mathrm{O}$ meio para isso é da maior facilidade na boa educação pública. É manter as crianças sempre sem fôlego, não por meio de tediosos estudos em que elas não entendem nada e que acabam por odiar pelo simples fato de que são forçadas a permanecer imóveis; mas por meio de exercícios que lhes agradem, satisfazendo à necessidade que, crescendo, tem o seu corpo de agitar-se e cujo prazer, para elas, não se limitará a isso. (ROUSSEAU, 1982, p. 38).

Assim, concluímos que há ligações entre as obras e que é preciso ler a concepção de Rousseau sobre educação no conjunto de suas obras, levando em conta os objetivos de cada uma delas. Uma vez superada a questão da circunstância de cada uma delas, podemos entender que os conceitos dialogam de modo claro. Não podíamos, portanto, concluir este trabalho antes de analisarmos a questão da pátria tão destacada nas Considerações que parecem muito antagônicas em relação ao Emílio.

\section{Conclusões}

Sem dúvida alguma o termo educação popular hoje utilizado por nós é anacrônico ao pensamento de Rousseau. No entanto, este anacronismo não nos impede de perceber que em suas obras estão presentes fundamentos que inspirarão uma percepção mais humana da educação. Quando se fala hoje educação humana, humanitária, ética, tratam de valores de relacionamento entre as pessoas, porém, pouco se fala em valorizar ao máximo aqueles profissionais que exercem determinados ofícios, cujos produtos são utilizados por todos, mas seus esforços são banalizados. No livro, vimos Rousseau valorizar os conhecimentos e os trabalhos de um jardineiro, de um mágico de rua e dos marceneiros, além de outras citadas ao longo da obra. O objetivo é desenvolver em Emílio a sensibilidade para a dimensão da existência humana, ou seja, entender que mesmo as pessoas não tendo formação escolar elevada, não sendo ricas, são pessoas cuja existência é tão complexa quanto de uma pessoa rica ou graduada, enfim, ontologicamente, seres humanos em sua plenitude. 


\section{Referências}

BEAUMONT, C. Carta Pastoral. In: Carta a Christophe de Beaumont e outros escritos sobre a Religião e a Moral. Tradução de José O. A. Marques (org.). São Paulo: Estação Liberdade, 2005, p. 221; O.C., Seuil, v. III, p. 331.

CHATÊAU, Jean. - Rousseau: sa philosophie de l'éducation, Paris, J. Vrin, 1962.

DERRIDA, Jacques. Gramatologia. Tradutores: Miriam Chaiderman e Renato Janine Ribeiro. São Paulo: Editora Perspectiva, 1973.

FORTES, Luís Roberto Salinas. Rousseau: da Teoria à Prática, São Paulo, Ática, 1976.

HOBBES, T., O Leviatã, in: Os Pensadores. Tradução de João Paulo Monteiro e Maria Beatriz Nizza da Silva. São Paulo: Nova Cultural, 1988.

ROUSSEAU, Jean-Jacques. Carta a Christophe de Beaumont e outros escritos sobre a Religião e a Moral. Tradução de José O. A. Marques (org.). São Paulo: Estação Liberdade, 2005, p. 50.

ROUSSEAU, Jean-Jacques. Carta à D'Alembert, tradução de Roberto Leal Ferreira, Campinas, UNICAMP, 1993.

ROUSSEAU, Jean-Jacques. Considerações sobre o Governo da Polônia e sua Reforma Projetada, tradução de Luiz Roberto Salinas Fortes, São Paulo, Brasiliense, 1982.

ROUSSEAU, Jean-Jacques. Emílio ou da Educação, tradução de Sérgio Milliet, Rio de Janeiro, Bertrand Brasil, 1991.

ROUSSEAU, Jean-Jacques. Oeuvres Complètes. Bibliothèque de la Plêiade. Paris: Gallimard, 1959 - 1995, 5 volumes. Lettre de J.-J. Rousseau à Philibert Cramer, 13 octobre 1764 in Correspondance complète, vol. 21. 